${ }^{1}$ Clinical Laboratory, Hospital Universitario de San Juan, San Juan de Alicante, Spain. ${ }^{2}$ Department of Biochemistry and Molecular Pathology, Universidad Miguel Hernández, Elche, Spain. ${ }^{3}$ Department of Clinical Medicine, Universidad Miguel Hernández, Elche, Spain.

${ }^{4}$ Department of Public Health, Universidad de Alicante, Alicante, Spain.

${ }^{5}$ Department of Radiology, University of Virginia,

Charlottesville, VA, USA.

Funding: This research received specific grant (Ignacio H. de Larramendi Aid to research) from Fundación Mapfre.

Recibido el 12 enero de 2016, aceptado el 2 junio de 2016.

Correspondencia a: María Salinas, PhD. Hospital Universitario de San Juan.

Carretera Alicante-Valencia, $\mathrm{s} / \mathrm{n}$, 03550 San Juan de Alicante, Alicante, Spain. salinas_mar@gva.es

\section{Requests of laboratory tests for the diagnosis and management of calcium-phosphate disorders in Spain}

\author{
MARÍA SALINAS ${ }^{1,2}$, MAITE LÓPEZ-GARRIGÓS ${ }^{1}$, EMILIO FLORES ${ }^{1,3}$, \\ JOAQUÍN URIS ${ }^{4}$, CARLOS LEIVA-SALINAS ${ }^{5}$
}

\section{ABSTRACT}

Background: Knowledge about the variability in the request of calcium-phosphate metabolism laboratory tests in primary care is important to design strategies to improve health system efficiency. Aim: To compare the inter-practice variability in calcium-phosphate metabolism laboratory tests requested by general practitioners from diverse regions across Spain. Material and Methods: One hundred and forty one clinical laboratories were invited to participate in an observational cross-sectional study. They informed the number of serum calcium, phosphate, parathyroid hormone and 25-hydroxyvitamin D requested by general practitioners. Appropriateness indicators were calculated as number of test requests per 1,000 inhabitants and ratio of related tests requests. The differences according to hospital setting, region and type of management were analyzed. Results: We recruited 76 laboratories (17,679,195 inhabitants). General practitioners requested 3,260,894 calcium-phosphate metabolism tests. The rate of request ranged from 2.97 per 1,000 inhabitants for 25 -hydroxyvitamin $D$ to 98.89 per 1,000 inhabitants for calcium. The rates of request for calcium, phosphate, parathyroid hormone in some areas were 30, 100 and 340 times higher than in other areas. Parathyroid hormone and 25-hydroxyvitamin D were highly requested in private management areas. There were also differences in phosphate, parathyroid hormone and 25-hydroxyvitamin D requesting between regions across Spain. Conclusions: The high variability observed is difficult to explain by differences in patient case mix between regions. Depending on the area, calcium could be under requested to detect primary hyperparathyroidism.

(Rev Med Chile 2016; 144: 990-997)

Key words: Calcium Metabolism Disorders; Clinical Laboratory Services; Practice Patterns, Physicians)

\section{Solicitud de pruebas de laboratorio para el diagnóstico y manejo de los desórdenes del metabolismo fosfocálcico en España}

Objetivo: Conocer la variabilidad en la solicitud de pruebas de laboratorio en atención primaria es importante para diseñar estrategias que mejoren la eficiencia del sistema de salud. La propuesta de este estudio fue comparar la variabilidad en la solicitud de pruebas para la evaluación del metabolismo fosfocálcico por médicos de atención primaria de diversas regiones de España. Material y 
Método: Se invitó a participar a 141 laboratorios clínicos de diversas regiones españolas. Completaron una encuesta con el número de determinaciones de calcio, fósforo, hormona paratiroidea y 25-hidroxivitamina D solicitadas por médicos de atención primaria de sus áreas. Se calcularon las tasas en relación a la población y se construyeron indicadores de adecuación. Los resultados se compararon por características del hospital, región y tipo de gestión. Resultados: Obtuvimos los datos de 76 laboratorios (17.679.195 habitantes). Los médicos de atención primaria solicitaron 3.260.894 pruebas de metabolismo fosfocálcico. La tasa de solicitud varió de 2,97 por 1.000 habitantes de 25-hidroxivitamin D a 98,89 por 1.000 habitantes de calcio. Las tasas de calcio, fósforo, hormona paratiroidea en algunas áreas fue 30, 100 y 340 veces más alta respecto a otras. Hormona paratiroidea y 25-hidroxivitamina D fueron más solicitadas significativamente en hospitales con gestión privada. También hubo diferencias en fósforo, hormona paratiroidea y 25-hidroxivitamina D solicitas entre distintas regiones de España. Discusión: La alta variabilidad observada es difícil de explicar por las diferencias de las características de los pacientes. Dependiendo de la región podría haber una infra solicitud para la detección del hiperparatiroidismo primario.

$\mathrm{H}$ ypercalcemia can be caused by many disorders, but is most commonly due to neoplastic disease in inpatients and to primary hyperparathyroidism (PHPT) in outpatients $^{1,2}$. PHPT is the third most common endocrine disease after diabetes and thyroid diseases ${ }^{3}$. Due to its mild symptoms, the disorder can be detected in primary care, through an unexpected hypercalcaemia. It is crucial to diagnose this highly prevalent disorder early in its clinical course, as timely treatment delays progression and prevents its devastating complications, thus improving prognosis $^{4-6}$.

Test requesting inappropriateness is a major issue for a healthcare system ${ }^{7,8}$; test under requesting results in misdiagnosis, on the other hand, over requesting produces unnecessary expenses, but even physical and psychological patient adverse effects $^{8-11}$.

There is high variability in the request of calcium (S-calcium) and phosphate (S-phosphate), between different regions, and referring physicians ${ }^{12-16}$. In certain areas, S-calcium is under-requested to detect asymptomatic PHPT ${ }^{14,15}$. Currently, through studies investigating regional and geographical differences in test request ${ }^{12,13,17,18}$, we can detect requesting inappropriateness, and deduce the root causes of such potential problem.

The aim of this research was to study the inter-practice variability in calcium-phosphate metabolism laboratory tests requested by General Practitioners (GPs) in Spain to investigate the degree in requesting appropriateness and deduce its potential causes.

\section{Materials and Methods}

\section{Data collection}

Encouraged by the previous pilot studies in the Valencian Community ${ }^{12}$ and all around Spain ${ }^{13-18}$ a call for data was posted via email. Spanish laboratories willing to participate in the study were invited to fill out an enrollment form and submit their results online. A total of 141 laboratories were invited to participate. We obtained production statistics (number of tests requested by GPs for the year 2012 from laboratories at different hospitals from diverse regions across Spain. Every patient seen in any primary care center (PCC) of any of these health departments, regardless of the reason for consultation, gender or age, was included in the study. Each participating laboratory was required to be able to obtain patient data from local databases and to provide organizational data (i.e. population served, public/private management, location). S-calcium, S-phosphate, albumin, parathyroid hormone (PTH) and 25-hydroxyvitamin $\mathrm{D}[25(\mathrm{OH}) \mathrm{D}]$ test requesting were examined in a cross-sectional study.

\section{Data processing}

After collecting the data, two types of appropriateness indicators were calculated: every test request per 1,000 inhabitants and ratio of related 
tests requests (S-phosphate/S-calcium; 25(OH)D/ $\mathrm{PTH})$. In order to explore the inter-practice variability, another indicator, the "index of variability", was calculated as follows: top decile divided by bottom decile (90th percentile/10th percentile).

We calculated if the rate of test requests was different according to the setting (rural, urban, or rural-urban) of the hospital and whether the institution had a public or private management.

Finally, the indicators results obtained in the laboratories in the three regions with the highest number of departments participating in the study were compared between them and to the pooled results of the remaining regions in order to establish whether there were regional differences in the requesting patterns.

\section{Statistical methods}

The statistical treatment of the calculated data included: the distribution, the mean, 95\% confidence level for the mean, standard deviation, median and interquartile range. The analysis of the distribution of the number of indicators results was conducted by way of the Kolmogorov-Smirnov test.

The differences in indicators results according to the hospital characteristics and per region were calculated by way of the Mann-Whitney $U$ or Kruskal-Wallis test analysis, as appropriate.

A two-sided $\mathrm{p} \leq 0.05$ rule was utilized as the criterion for rejecting the null hypothesis of no difference.

\section{Results}

We obtained production statistics from 76 laboratories at different hospitals from diverse regions across Spain. 17,679,195 patients $(37.8 \%$ of the Spanish population) were included in the study, from 13 Communities (Valencian Community, 23 laboratories and 4,848,900 patients ( $96.9 \%$ of the Valencian Community population); Andalucía, 12 laboratories and 3,849,485 patients (37.8\% of Andalucía population); Castilla y León, 9 laboratories and $1,695,916$ patients $(67.1 \%$ of Castilla y León population) and other region, 32 laboratories and 7,284,889 patients). GPs requested 3,260,894 calcium-phosphate metabolism laboratory tests. A summary of the organizational data of the different laboratories that participated in the study is showed in Table 1.

Table 2 shows the descriptive statistical analysis and the variability index for the indicator results. The rates of request for S-calcium, S-phosphate and PTH in some areas were 30, 100 and 340 times higher than in other areas respectively.

GPs requested albumin to the 76 laboratories. However, only 17 laboratories additionally provided calcium corrected per albumin.

Table 3 compares the appropriateness indica-

Table 1. Descriptive characteristics of the hospitals/health care departments that participated in the study

\begin{tabular}{|c|c|c|}
\hline Descriptive characteristics & & Data \\
\hline Areas (n) & & 76 \\
\hline Subjects (n) & & $17,679,195$ \\
\hline Population/area [mean (Cl95\%)] & & $232,621(200,099.8-265,142.2)$ \\
\hline Location [n (\%)] & $\begin{array}{l}\text { Valencian Community } \\
\text { Andalucía } \\
\text { Castilla y León } \\
\text { Other región }\end{array}$ & $\begin{array}{r}23(30.3 \%) \\
12(15.8 \%) \\
9(11.8 \%) \\
(42.1 \%)\end{array}$ \\
\hline Type of Management [n (\%)] & $\begin{array}{l}\text { Public } \\
\text { Private }\end{array}$ & $\begin{array}{r}70(92.1 \%) \\
6 \quad(7.9 \%)\end{array}$ \\
\hline Setting [n (\%)] & $\begin{array}{l}\text { Urban } \\
\text { Rural } \\
\text { Urban-rural }\end{array}$ & $\begin{array}{r}15(19.7 \%) \\
3(3.9 \%) \\
58(76.3 \%)\end{array}$ \\
\hline
\end{tabular}

$\mathrm{Cl}$ : Confidence interval of the mean. 
tors results obtained at the different laboratories according to their setting and type of management. $\mathrm{PTH}$ and $25(\mathrm{OH}) \mathrm{D}$ that were higher requested in areas with private management.

Table 4 compares the number of requests per 1,000 inhabitants in the different regions. There were no differences in S-calcium requesting, however S-phosphate was higher requested in Castilla y León when compared to Andalucía. PTH and 25(OH)D were over requested in Valencian Community when compared to Castilla y León, Andalucía and the remaining regions.

Table 2. Descriptive statistical analysis and the variability index

\begin{tabular}{|c|c|c|c|c|c|c|c|}
\hline & & Range & Mean & Cl95\% & Median & IQR & $\begin{array}{c}\text { Variability } \\
\text { Index }\end{array}$ \\
\hline $\begin{array}{l}\text { Tests/1,000 } \\
\text { inhabitants }\end{array}$ & $\begin{array}{l}\text { S-calcium } \\
\text { S-phosphate } \\
\text { PTH } \\
250 H D \\
\text { Albumin }\end{array}$ & $\begin{array}{c}11.37-334.10 \\
2.29-230.66 \\
0.05-17.77 \\
0.03-21.19 \\
0.25-231.84\end{array}$ & $\begin{array}{r}98.89 \\
61.29 \\
3.01 \\
2.97 \\
55.38\end{array}$ & $\begin{array}{c}82.55-115.23 \\
49.15-73.43 \\
2.07-3.94 \\
1.93-4 \\
41.73-69.02\end{array}$ & $\begin{array}{r}88.38 \\
45.17 \\
1.55 \\
1.11 \\
31.20\end{array}$ & $\begin{array}{r}80.96 \\
65.29 \\
1.89 \\
1.79 \\
56.93\end{array}$ & $\begin{array}{r}7.63 \\
16.82 \\
23.15 \\
51.65 \\
31.89\end{array}$ \\
\hline $\begin{array}{l}\text { Related test } \\
\text { requested ratios }\end{array}$ & $\begin{array}{l}\text { 25OHD/PTH } \\
\text { S-phosphate/ S-calcium }\end{array}$ & $\begin{array}{l}0.015-9.004 \\
0.046-0.993\end{array}$ & $\begin{array}{l}1.336 \\
0.621\end{array}$ & $\begin{array}{l}0.937-1.735 \\
0.558-0.685\end{array}$ & $\begin{array}{l}0.861 \\
0.659\end{array}$ & $\begin{array}{l}0.987 \\
0.492\end{array}$ & $\begin{array}{r}14.85 \\
4.62\end{array}$ \\
\hline
\end{tabular}

Legend: Serum calcium (S-calcium); phosphate (S-phosphate); parathyroid hormone (PTH) and 25-hydroxyvitamin D [25(OH)D].

Table 3. Differences of appropriateness indicators results obtained at the laboratories of the different locations and according to the type of management

\begin{tabular}{|c|c|c|c|c|c|c|c|}
\hline \multirow[t]{2}{*}{ S-calcium } & & \multicolumn{4}{|c|}{$\begin{array}{c}\text { Test per 1,000 inhabitants } \\
(\text { (mean } \pm \text { SD) }\end{array}$} & \multirow{2}{*}{\multicolumn{2}{|c|}{$\begin{array}{l}\text { Ratios of related tests } \\
\text { (mean } \pm \text { SD) }\end{array}$}} \\
\hline & & S-phosphate & PTH & 25(OH)D & $\begin{array}{l}\text { S-phosphate/ } \\
\text { S-calcium }\end{array}$ & & \\
\hline Location & $\begin{array}{l}U \\
R \\
U-R\end{array}$ & $\begin{array}{r}131.95 \pm 81.30 \\
64.29 \pm 25.70 \\
92.13 \pm 68.42\end{array}$ & $\begin{array}{l}87.62 \pm 48.62 \\
24.57 \pm 2.20 \\
56.38 \pm 53.44\end{array}$ & $\begin{array}{l}4.37 \pm 5.08 \\
1.66 \pm 0.82 \\
2.72 \pm 3.85\end{array}$ & $\begin{array}{l}5.10 \pm 6.53 \\
0.80 \pm 0.40 \\
2.51 \pm 3.75\end{array}$ & $\begin{array}{l}0.757 \pm 0.235 \\
0.428 \pm 0.187 \\
0.596 \pm 0.282\end{array}$ & $\begin{array}{l}1.014 \pm 0.597 \\
0.483 \pm 0.096 \\
1.469 \pm 1.939\end{array}$ \\
\hline Management & $\begin{array}{l}\text { P } \\
\text { PV }\end{array}$ & $\begin{aligned} 98.51 & \pm 72.22 \\
103.31 & \pm 25.12\end{aligned}$ & $\begin{array}{l}59.51 \pm 54.44 \\
81.98 \pm 29.92\end{array}$ & $\begin{array}{r}2.37 \pm 3.03^{\dagger} \\
10.42 \pm 7.11\end{array}$ & $\begin{array}{l}2.54 \pm 4.03^{\dagger} \\
7.75 \pm 6.76\end{array}$ & $\begin{array}{l}0.608 \pm 0.282 \\
0.781 \pm 0.166\end{array}$ & $\begin{array}{l}1.395 \pm 1.783 \\
0.669 \pm 0.356\end{array}$ \\
\hline
\end{tabular}

* Kruskal-Wallis test significative $(p<0.05)$; +U-Mann-Whitney test significative $(p<0.05)$.

Table 4. Differences of appropriateness indicators results obtained at the laboratories of the different regions of Spain

\begin{tabular}{|c|c|c|c|c|c|c|}
\hline & \multicolumn{3}{|c|}{$\begin{array}{l}\text { Tests/1,000 inhabitants } \\
\text { (mean } \pm \text { SD) }\end{array}$} & \multirow[b]{2}{*}{ 25(OH)D } & \multicolumn{2}{|c|}{$\begin{array}{l}\text { Ratio of related tests } \\
\text { (mean } \pm \text { SD) }\end{array}$} \\
\hline & S-calcium & S-phosphate & PTH & & $\begin{array}{l}\text { S-phosphate/ } \\
\text { S-calcium }\end{array}$ & 25(OH)D/PTH \\
\hline V & $91.93 \pm 76.01$ & $52.70 \pm 48.50$ & $5.71 \pm 5.97^{*}$ & $6.11 \pm 6.26^{*}$ & $0.604 \pm 0.250$ & $0.852 \pm 0.303$ \\
\hline A & $117.08 \pm 106.75$ & $39.87 \pm 41.36$ & $2.41 \pm 3.44$ & $1.48 \pm 2.41$ & $0.415 \pm 0.292$ & $0.898 \pm 0.626$ \\
\hline $\mathrm{CL}$ & $119.83 \pm 51.91$ & $109.34 \pm 56.66^{*}$ & $1.07 \pm 0.64$ & $0.78 \pm 0.50$ & $0.886 \pm 0.090 *$ & $1.528 \pm 2.180$ \\
\hline OR & $91.18 \pm 56.35$ & $61.98 \pm 53.12$ & $1.83 \pm 1.57$ & $1.79 \pm 2.62$ & $0.637 \pm 0.271$ & $1.481 \pm 1.705$ \\
\hline
\end{tabular}

*Kruskal-Wallis test ( $p$ value $<0.05$ ); Legend: VC: Valencian Community; A: Andalucía; CL: Castilla y León; OR: Other regions. Serum calcium (S-calcium); phosphate (S-phosphate); parathyroid hormone (PTH) and 25-hydroxyvitamin D [25(OH)D]. S-phosphate request in $\mathrm{CL}$ was significantly higher than in $\mathrm{A}$; $\mathrm{PTH}$ and $25(\mathrm{OH}) \mathrm{D}$ in $\mathrm{V}$ were significantly higher than $\mathrm{A}, \mathrm{CL}$ and $\mathrm{OR}$; S-phosphate/ S-calcium in CL significantly higher than A, V and OR. 


\section{Discussion}

There were significant differences in the request of calcium-phosphate metabolism laboratory tests, as seen in prior investigations ${ }^{12,13}$. The variability observed for S-calcium in the study was from 11.37 to 334.10 tests per 1,000 inhabitants. This variability could be explained in the different areas by case mix variations, or the possible variability in the patient demographic. However the differences observed between areas are so high that it was probably caused by additional reasons.

Hypercalcaemia is a highly prevalent condition $^{19}$, up to of $3.9 \%$ of the general population ${ }^{20}$. Eleven requests of S-calcium tests per 1,000 inhabitants, as in certain areas, indicate that, on average, every patient would get a test ordered every 100 years. In this scenario, S-calcium may be under requested for two main reasons. First, S-calcium is crucial to detect asymptomatic $\mathrm{PHPT}^{14}$. Second S-calcium testing does not usually yield false positive results with a proper sampling technique ${ }^{21}$. At least $88 \%$ of patients with hypercalcaemia will turn out to have an underlying disorder during a 10-year follow-up period, which makes necessary careful investigation of such subjects ${ }^{22}$.

Asymptomatic PHPT is usually detected in health screenings. With the introduction of automated S-calcium measurement with multichannel continuous-flow analyzers in the 1970s, this silent disease began to be detected ${ }^{23}$. At that time, unexpected high S-calcium values on serum biochemical screening contributed to the diagnosis of 250 new cases of PHPT per million inhabitants per year ${ }^{24}$. Then, the disappearance of the multichannel analyzers and simultaneous introduction of random access analyzers, that in general would benefit the appropriate laboratory test requesting by demanding and measuring only those tests related to a certain diagnosis, resulted in S-calcium under requesting and, hence, a decreased detection of asymptomatic PHPT ${ }^{25}{ }^{26}$. PHPT became a not so infrequent disease that was often overlooked by physicians ${ }^{27}$. In fact, with the disappearance of multichannel continuous-flow analyzers S-calcium is at risk of being the "forgotten test", and strategies must be encouraged to increase its request for a correct PHPT detection ${ }^{14}$.

The prevalence of PHPT in Spain varies between 1 and 4/1,000 in the general population ${ }^{28}$. Lately, thanks to the establishment of PHPT screening strategies, it is even increasing ${ }^{14}$. Depending on the criteria used to define PHPT, the prevalence of the disorder in older women ranges from $3.6 \%$ to $13.9 \%$, making it really important to define hypercalcemia as a first step to detect the disorder ${ }^{29}$. Total calcium (S-calcium) occurs in plasma in free form, "ionized calcium", and in complex bound form, especially with albumin ${ }^{30}$. It is only ionized calcium which is physiologically relevant, and this would be the fraction to be measured. Methods are available, but they require specially analyzers and rapid anaerobic handling of the sample. So, in most clinical situations disturbances in calcium metabolism have to be assessed from changes in the S-calcium concentration. As ionized calcium, the biologically active, is unstable in PCCs samples, it is crucial the calculation of total calcium corrected per albumin. It is true that calcium binding to albumin is influenced by $\mathrm{pH}$ and hence by stasis, but within the range found in current clinical practice the proportion of S-calcium which is bound varies little ${ }^{31}$. However, as showed in our study results, only $22 \%$ of laboratories reported albumin-corrected calcium.

The interest of measuring S-phosphate is always related to $S$-calcium. The request of $S$-phosphate ranged from a one to one ratio when compared to S-calcium request, to almost zero. S-phosphate should be probably only requested based on algorithms after abnormal values of $\mathrm{S}$-calcium, as performed with aminotransferases ${ }^{32}$ or thyroid hormones ${ }^{33}$.

The variability in PTH and 25(OH)D requesting was even higher than that for S-calcium and S-phosphate and is very difficult to interpret, mainly for two reasons. First, we do not know if the different request patterns could be explained by the different implication of GPs in the management of calcium-phosphate metabolism disorders in the different areas. Second, there are no prior studies regarding $\mathrm{PTH}$ and $25(\mathrm{OH}) \mathrm{D}$ request in primary care to compare with. Both tests were over requested in areas with private management. This could be explained by the fact that this type of management is new, and physicians working in such areas may be more prone to manage calcium-phosphate metabolism disorders. The fact that these areas with private management are located in Valencian Community could explain or at least could contribute to the over 
request of such tests in Valencian Community, when compared to other regions. Additionally, it seems plausible that centers that are interested in hyperparathyroid disorders request more of all these markers. There was a high variability in the ratio $25(\mathrm{OH}) \mathrm{D} / \mathrm{PTH}$ between the different areas, which ranged from 0.015 to 9 . More studies are necessary to explain those striking results. Along the last years, hypovitaminosis D has been associated with many clinical condition (immunology and oncology disorders) there was a spread of $25(\mathrm{OH})$ $\mathrm{D}$ test requests among different centers other than those specialized in metabolic bone disease and also among general practitioners ${ }^{34}$.

The strength of this study includes the national representation of the studied population; this allows us to provide accurate estimates of indicator calculation. Nonetheless, the study had certain limitations. First, the differences in calcium-phosphate metabolism laboratory tests request between health care regions in Spain could be partly explained by case mix variations in the different areas, or the possible variability in the patient population. Second, we did not take into account the differences in blood sampling techniques and the distribution of age, gender, medication and body mass index of the subjects at the different participating laboratories. Third, we did not evaluate the request of ionized calcium, because we did not get those data, and another potential indicators as S-calcium/PTH Also, the variability showed in our study could be explained by regional different degrees of awareness in the management of calcium-phosphate disorders in primary care. Finally, it is difficult to know whether there is over or under request without clinical patient data.

In all, there was high variability in the request of calcium-phosphate tests in almost half of the Spanish population, difficult to explain by differences in patient case mix between regions. S-calcium was probably under requested in some areas to detect silent diseases such as PHPT. Great efforts must be done from every stakeholder that intervenes in calcium-phosphate metabolism disorders, mainly S-calcium and $\mathrm{PTH}$ requests should be homogeneous, as they are basic for PHPT diagnosis.

Acknowledgments: Members of the REDCON$\mathrm{LAB}$ working group are the following (in alpha- betical order): Alfonso Pérez-Martínez (Hospital Morales Meseguer); Amparo Miralles (Hospital de Sagunto); Ana Santo-Quiles (Hospital Virgen de la Salud, Elda); Ángela Rodríguez-Piñero (Hospital Universitario de Móstoles); Ángeles Giménez-Marín (Hospital de Antequera); Antonio Buño-Soto (Hospital La Paz, Madrid); Antonio Gómez del Campo (Complejo Asistencial de Ávila); Antonio León-Juste (Hospital Juan Ramón Jiménez, Huelva); Antonio Moro-Ortiz (Hospital de Valme, Sevilla); Begoña Laiz (Hospital Universitario y Politécnico La Fe de Valencia); Berta González-Ponce (Hospital Da Costa, Burela); Carmen Hernando de Larramendi (Hospital Severo Ochoa de Leganés); Carmen Vinuesa (Hospital de Vinaros); Cesáreo García-García (Hospital Universitario de Salamanca); Concepción Magadán-Núñez (Hospital Arquitecto Marcide, El Ferrol); Consuelo Tormo (Hospital General Universitario de Elche); Cristina Santos-Rubio (Hospital Río Tinto, Huelva); Cristóbal Avivar (Hospital de Poniente, El Ejido); Diego Benítez Benítez (Hospital de Orihuela); Eduardo Sánchez-Fernández (Hospital del Vinalopo, Elche); Emilia Moreno-Noguero (Hospital Can Misses); Enrique Rodríguez-Borja (Hospital Clínico Universitario de Valencia); Esther Roldán-Fontana (Hospital La Merced. Area de Gestión Sanitaria Sevilla Este); Fco. Javier Martín Oncina (Hospital Virgen del Puerto de Plasencia, Cáceres); Félix Gascón (Hospital Valle de los Pedroches, Pozoblanco); Fernando Rodríguez Cantalejo (Hospital Universitario Reina Sofía de Córdoba); Fidel Velasco Pena (Hospital Virgen de Altagracia, Manzanares); Francisco Miralles (Hospital Lluis Alcanyis, Xàtiva); Goitzane Marcaida (Consorcio Hospital General Universitario de Valencia); Marta Barrionuevo (Hospital Universitario Principe de Asturias, Alcalá de Henares); Inmaculada Domínguez-Pascual (Hospital General Universitario Virgen del Rocío, Sevilla); Isidoro Herrera Contreras (Complejo Hospitalario de Jaén); José Antonio Ferrero (Hospital General de Castellón); José Luis Barberà (Hospital de Manises); José Luis Quilez Fernández (Hospital Universitario Reina Sofía de Murcia); Jose Luis Ribes-Vallés (Hospital de Manacor); José Miguel González Redondo (Hospital Santiago Apóstol de Miranda de Ebro); José Sastre (Hospital Virgen de los Lirios, Alcoy); José Vicente García-Lario (Hospital Virgen de las Nieves, Granada); Juan Ignacio Molinos (Hospital Sierrallana, Torre- 
lavega); Juan Molina (Hospital Comarcal de La Marina, Villajoyosa); Juan Ramón Martínez-Inglés (Hospital General Universitario Santa Lucía, Cartagena); Julián Díaz (Hospital Francesc de Borja, Gandia); Laura Navarro Casado (Complejo Hospitalario Universitario de Albacete); Leopoldo Martín-Martín (Hospital General de La Palma); Lola Máiz Suárez (Hospital Universitario Lucus Augusti, HULA, Lugo); Luís Rabadán (Complejo Asistencial de Soria); M. Dolores Calvo (Hospital Clínico de Valladolid); M. Amalia Andrade-Olivie (Hospital Xeral-Cies, CHU Vigo); M. Ángeles Rodríguez-Rodríguez (Complejo Asistencial de Palencia); M. Carmen Gallego Ramírez (Hospital Rafael Méndez, Lorca); M. Mercedes Herranz-Puebla (Hospital Universitario de Getafe); M. Victoria Poncela-García (Hospital Universitario de Burgos); $\mathrm{M}^{\mathrm{a}}$ José Baz (Hospital de Llerena, Badajoz); Ma José Martínez-Llopis (Hospital de Denia); Ma Teresa Avello-López (Hospital San Agustín, Avilés); Mabel Llovet (Hospital Verge de la Cinta, Tortosa); Mamen Lorenzo (Hospital de Puertollano); Marcos López-Hoyos (Hospital Universitario Marqués de Valdecilla); María José Zaro (Hospital Don Benito-Villanueva); María Luisa López-Yepes (Hospital Virgen del Castillo de Yecla); Mario Ortuño (Hospital Universitario La Ribera); Marisa Graells (Hospital General Universitario de Alicante); Marta García-Collía (Hospital Ramón y Cajal, Madrid); Martín Yago (Hospital de Requena); Mercedes Muros (Hospital Nuestra Señora de la Candelaria, Tenerife); Nuria Estañ (Hospital Dr. Peset, Valencia); Nuria Fernández-García (Hospital Universitario Río Hortega, Valladolid); Pilar García-Chico Sepúlveda (Hospital General Universitario de Ciudad Real); Ricardo Franquelo (Hospital Virgen de la Luz de Cuenca); Ruth González Tamayo (Hospital de Torrevieja); Silvia Pesudo (Hospital La Plana); Vicente Granizo-Domínguez (Hospital Universitario de Guadalajara); Vicente Villamandos-Nicás (Hospital Santos Reyes, Aranda del Duero); Vidal Pérez-Valero (Hospital Regional de Málaga).

\section{References}

1. Evans RA. Hypercalcaemia. What does it signify? Drugs 1986; 31 (1): 64-74.

2. Lafferty FW. Differential diagnosis of hypercalcemia. J Bone Miner Res 1991; 6 (2): S51-9.
3. Harrison BJ, Wheeler MH. Asymptomatic primary hyperparathyroidism. World J Surg 1991; 15 (6): 724-9.

4. Weber T, Eberle J, Messelhäuser U, Schiffmann L, Nies C, Schabram J, et al. Parathyroidectomy, elevated depresion scores, and suicidal ideation in patients with primary hyperparathyroidism. Results of prospective multicenter study. JAMA Surg 2013; 148 (2): 109-15.

5. Walker MD, Rundek T, Homma S, Di Tullio M, Iwata S, Lee JA, et al. Effect of parathyroidectomy on subclinical cardiovascular disease in mild primary hyperparathyroidism. Eur J Endocrinol 2012; 167 (2): 277-85.

6. Rubin MR, Bilezikian JP, McMahon DJ, Jacobs T, Shane E, Siris E, et al. The natural history of primary hyperparathyroidism with or without parathyroid surgery after 15 years. J Clin Endocrinol Metab 2008; 93 (9): 3462-70.

7. van Walraven C, Naylor CD. Do we know what inappropriate laboratory utilization is? A systematic review of laboratory clinical audits. JAMA 1998; 280 (6): 550-8.

8. Salinas M, López-Garrigós M, Uris J, Leiva-Salinas C, Pilot Group of the Appropriate Utilization of Laboratory Tests (REDCONLAB) working group. A study of the differences in the request of glycated hemoglobin in primary care in Spain: A global, significant, and potentially dangerous under-request. Clin Biochem 2014; 47 (12): 1104-7.

9. Rang M. The Ulysses syndrome. Can Med Assoc J 1972; 106 (2): 122-3.

10. Salinas M, López-Garrigós M, Leiva-Salinas C. False positive results: The imaginary invalid syndrome. Aten Primaria 2013; 45 (10): 542.

11. Salinas M, López-Garrigós M, Flors L, Leiva-Salinas C. Laboratory false-positive results: a clinician responsibility or a shared responsibility with requesting clinicians? Clin Chem Lab Med 2013; 51 (9): e199-200.

12. Salinas M, López-Garrigós M, Díaz J, et al. Regional variations in test requiring patterns of general practitioners in Spain. Ups J Med Sci 2011; 116 (4): 247-51.

13. Salinas M, López-Garrigós $M$, Tormo $C$, Ortuño $M$, Yago M, Laíz B, et al. Primary care use of laboratory tests in Spain: measurement through appropriateness indicators. Clin Lab 2014; 60 (3): 483-90.

14. Salinas M, López-Garrigós M, Pomares F, Lugo J, Asencio A, López-Penabad L, et al. Serum calcium (S-Ca), the forgotten test: preliminary results of an appropriateness strategy to detect primary hyperparathyroidism (pHPT). Bone 2013; 56 (1): 73-6.

15. Dalemo S, Hjerpe P, Ohlsson H, Eggertsen R, Merlo J, Boström KB. Variation in plasma calcium analysis in primary care in Sweden-a multilevel analysis. BMC Fam Pract 2010; 30 (11): 43.

16. Dalemo S, Hjerpe P, Boström Bengtsson K. Diagnosis of 
patients with raised serum calcium level in primary care, Sweden. Scand J Prim Health Care 2006; 24 (3): 160-5.

17. Larsson A, Palmer M, Hultén G, Tryding N. Large differences in laboratory utilisation between hospitals in Sweden. Clin Chem Lab Med 2000; 38 (5): 383-9.

18. Salinas M, López-Garrigós M, Uris J; Pilot Group of the Appropriate Utilization of Laboratory Tests (REDCONLAB) Working Group. Differences in laboratory requesting patterns in emergency department in Spain. Ann Clin Biochem 2013; 50 (4): 353-9.

19. Palmer M, Jakobsson S, Akerström G, Ljunghall S. Prevalence of hypercalcaemia in a health survey: a 14-year follow-up study of serum calcium values. Eur J Clin Invest 1988; 18 (1): 39-46.

20. Christensson T, Hellström K, Wengle B, Alveryd A, Wikland B. Prevalence of hypercalcaemia in a health screening in Stockholm. Acta Med Scand 1976; 200 (12): 131-7.

21. Phillips PJ, Pain RW, Hartley TF, Duncan BM, Atkinson MJ. Current "corrected" calcium concept rechallenged. Clin Chem 1977; 23 (10): 1938-9.

22. Dalemo S, Eggertsen R, Hjerpe P, Jansson S, Almqvist EG, Bengtsson Boström K. Long-term follow-up of patients with elevated serum calcium concentrations in Swedish primary care. Scand J Prim Health Care 2013; 31 (4): 248-54.

23. Bowman WD. Primary hyperparathyroidism. Before and after development of routine screening tests. Rocky Mt Med J 1972; 69 (5): 53-6.

24. Mundy GR, Cove DH, Fisken R. Primary hyperparathyroidism: changes in the pattern of clinical presentation. Lancet 1980; 1 (8182): 1317-20.

25. Lundgren E, Rastad J, Thrufjell E, Akerström G, Ljunghall S. Population-based screening for primary hyperparathyroidism with serum calcium and parathyroid hormone values in menopausal women. Surgery 1997; 121 (3): 287-94.

26. Press DM, Siperstein AE, Berber E, Shin JJ, Metzger R, Monteiro R, et al. The prevalence of undiagnosed and unrecognized primary hyperparathyroidism: a population-based analysis from the electronic medical record. Surgery 2013; 154 (6): 1232-7.

27. Janssens L, Verbeke V, Petrossians P, Dubois B, Godon E, Godon JP, et al. Primary hyperparathyroidism: etiology, diagnosis and treatment. Rev Med Liege 2000; 55 (11): 977-85.

28. Muñoz Torres M, Jodar Gimeno E, Reyes García R, Martínez Díaz Guerra G, Amado JA, Gaztambide S, et al. Results from a national survey on the management of primary hyperparathyroidism. J Endocrinol Invest 2012; 35 (11): 957-63.

29. Benson L, Ljunghall S, Groth T, Falk H, Hvarfner A, Rastad J, et al. Optimal discrimination of mild hyperparathyroidism with total serum calcium, ionized calcium and parathyroid hormone measurements. Ups J Med Sci 1987; 92 (2): 147-76.

30. Orrell DH. Albumin as an aid to the interpretation of serum calcium. Clin Chim Acta 1971; 35 (2): 483-9.

31. Phillips P, Pain R. Correcting the calcium. Br Med J 1977; 1 (6074): 1473.

32. Lepper PM, Dufour JF. Elevated transaminases-what to do if everything was done? Praxis (Bern 1994) 2009; 98 (6): 330-4.

33. Srivastava R, Bartlett WA, Kennedy IM, Hiney A, Fletcher C, Murphy MJ. Reflex and reflective testing: efficiency and effectiveness of adding on laboratory tests. Ann Clin Biochem 2010; 47 (3): 223-7.

34. Brandi ML, Minisola S. Calcidiol [25(OH)D3]: from diagnostic marker to therapeutical agent. Curr Med Res Opin 2013; 29 (11): 1565-72. 